\title{
Gender Differences in Student Engagement Among African American Undergraduates at Historically Black Colleges and Universities
}

\author{
Shaun R. Harper Robert M. Carini Brian K. Bridges John C. Hayek
}

Differences in student engagement between women and men at historically Black colleges and universities (HBCUs) are examined in this study. Data were collected from 1,167 African American undergraduate students at 12 four-year HBCUs that participated in the National Survey of Student Engagement. Controlling for several factors that might obscure gender differences, the results counter previous research regarding gender gaps on HBCU campuses by illustrating that African American women enjoy an equally engaging experience as their same-race male counterparts.

The experiences of African American students at postsecondary educational institutions have received considerable attention in the higher education literature throughout the past 20 years. Several researchers have compared various dimensions of the undergraduate experience at Historically Black colleges and universities (HBCUs) to the African American student experience at predominantly White institutions (PWIs) (i.e., Allen, 1986; Bohr, Pascarella, Nora, \& Terenzini, 1995; Cheatham, Slaney, \& Coleman, 1990; Cokley, 1999; DeSousa \& Kuh, 1996; Fleming, 1984; Flowers \& Pascarella, 1999; Watson \& Kuh, 1996). These comparative studies overwhelmingly indicate that HBCUs, in spite of their poorer financial resources, offer better learning environments and support outlets for African American undergraduates, thus more positively affecting African American student outcomes.

HBCU-PWI comparative studies have added much-needed credibility and legitimacy to historically Black institutions during an era of forced desegregation and skepticism regarding their continued existence. However, most of the recently published research has neglected to consider exclusively the impact and effectiveness of HBCUs in serving African American students. That is, inquiry involving the study of HBCUs throughout the past 2 decades has mostly occurred at the expense of comparing those institutions to their predominantly White counterparts. Consequently, insight into engagement trends and student outcomes on HBCU campuses alone has not been sufficiently provided in the mainstream higher education literature in recent years. Little is known about how HBCU students spend their time and the extent to which they are actively engaged in educationally purposeful activities.

The gains and outcomes associated with student engagement have been consistently explored and well-documented. In fact, Kuh, Schuh, Whitt, and associates concluded, "The research is unequivocal: students who

Shaun R. Harper is Assistant Professor and Executive Director of the Doctor of Education Program at the University of Southern California Rossier School of Education. Robert M. Carini is Assistant Professor of Sociology at the University of Louisville. Brian K. Bridges is Associate Director of the Indiana University Center for Postsecondary Research and the BEAMS Project. John C. Hayek is Senior Associate Director of the Indiana University Center for Postsecondary Research and the National Survey of Student Engagement. 
are actively involved in both academic and out-of-class activities gain more from college than those who are not so involved" (1991, p. xi). Given this, it is important to systematically monitor engagement trends to determine who is involved in what and explore variances that exist among various student subgroups at different institutions. Engagement-related gains and student satisfaction have been widely studied across the two institutional types (HBCUs and PWIs) and among different racial/ethnic groups on predominantly White campuses, but recent empirical work has neglected to consider within-group differences at HBCUs.

In the 1980s, researchers found significant engagement gaps among female and male students at HBCUs, which led to stifled outcomes for African American women (Allen, 1986; Fleming, 1984). Our current study was an exploration of engagement trends to determine if gaps still exist between women and men at these institutions. Secondarily, we also examined self-reported gains and levels of satisfaction among African American students on historically Black campuses. Given the indisputable nexus that exists between student engagement, satisfaction, gains, and outcomes, evidence of enduring gender differences could offer important implications for faculty and student affairs professionals at HBCUs.

\section{Literature Review}

Several researchers have found that active engagement, both inside and outside of the classroom, positively affects a wide range of student outcomes, including cognitive and intellectual skill development (Anaya, 1996; Baxter Magolda, 1992; Kuh, 1995; Ory \& Braskamp, 1988; Pike, 2000); college adjustment (Cabrera, Nora, Terenzini,
Pascarella, \& Hagedorn, 1999; Clarke \& Tomlinson-Clarke, 1994; Delvin, 1996; Paul $\&$ Kelleher, 1995); moral and ethical development (Evans, 1987; Jones \& Watt, 1999; Liddell \& Davis, 1996; Rest 1993); psychosocial development and positive images of self (Bandura, Peluso, Ortman, \& Millard, 2000; Chickering \& Reisser, 1993; Harper, 2004; Pascarella, Smart, Ethington, \& Nettles, 1987; Taylor \& Howard-Hamilton, 1995); and persistence rates (Berger \& Milem, 1999; Braxton, Hirschy, \& McClendon, 2004; Braxton, Milem, \& Sullivan, 2000; Milem \& Berger, 1997; Peltier, Laden, \& Matranga, 1999; Tinto, 1993).

Many HBCU/PWI comparative studies have considered the effects of engagement on African American student outcomes. These studies consistently suggest that HBCUs offer a wider array of culturally appealing venues for African American student engagement and more effectively enhance several of the aforementioned outcomes. For instance, Fleming's (1984) analysis confirmed that most African American students felt a greater sense of connectedness, power, and affiliation on HBCU campuses than at PWIs, which subsequently impacted their cognitive and intellectual development. Berger and Milem (2000) found that HBCU students offered significantly higher self-ratings in three domains of self-concept-psychosocial wellness, academic self-efficacy, and achievement orientation - than their same-race peers attending PWIs. Reportedly, African American students at HBCUs also devote more effort to academic activities; experience more significant gains in intellectual development, critical thinking, and cultural awareness; and enjoy greater personal and social benefits than African Americans at 
PWIs (DeSousa \& Kuh, 1996). Additionally, Harvey and Williams' (1996) study further notes that participatory ethos and an engaging environment are among the many luxuries extended to African American students on historically Black campuses.

Despite the comparative evidence that portrays HBCUs as highly engaging institutions for African American students, previous studies exclusively involving HBCU students presented some alarming statistics regarding gender inequities and called attention to the often disengaging experiences of African American undergraduate women on those campuses. Gurin and Epps (1975) were the first known researchers to examine gender differences among HBCU students. Data collected from more than 5,000 African American students at ten HBCUs in the late 1960s indicated that undergraduate women were considerably disadvantaged. Specifically, female students' educational and career goals were substantially lower than those of male students; HBCU undergraduate men were 3 times more likely than women to express the intent to enroll in graduate and professional schools (especially Ph.D. programs); and women were more likely to aspire to lower-prestige careers in the "female sector" of the job market (e.g., teaching, nursing, secretarial positions). Gurin and Epps concluded that "patriarchal" HBCU environments promoted these lower levels of aspiration among African American women.

Fleming's (1984) results regarding gender inequities confirmed the findings presented by Gurin and Epps in the previous decade. She found that African American men on HBCU campuses - much like White male undergraduates at PWIs - felt potent, empowered, and "in charge." Consistent with Gilligan's (1993) assertions regarding the psychosocial differences between women and men, Fleming discovered that men at HBCUs dominated classroom and social environments and were far more competitive, thus yielding unfavorable outcomes for African American women.

It seems that when there are men around who are flexing their assertive muscles, there is no room for Black women to do the same. This basic pattern of women failing to translate their academic gains into good career development holds true in most of the Black colleges studied. (1984, p. 144)

The institutional nurturing of male dominance often created a discouraging and disengaging experience for African American women. Because engagement was substantially low among female students, their identities were often shaped by institutionalized messages of passivity. On many campuses in Fleming's sample, instructors had the most profound effect on female student disengagement, as women sat passively in their classes and received noticeably less support and attention from faculty than their male classmates. Fleming's findings also suggest that women lacked social assertiveness on HBCU campuses and competed less when there were large numbers of men present. Moreover, male students reported significantly higher levels of satisfaction with their in-class experiences and held more positive feelings toward their instructors. The primary research question in Fleming's study was "who gets the most out of college?" Based on the findings, she concluded, "It turns out to be a man's world. Women usually bring up the rear. In predominantly Black colleges, men gain the most" (1984, p. 138).

Consistent with data from Fleming's (1984) study, Allen (1986) found that African 
American female students had better high school grades than African American men, but experienced a more dramatic decrease in academic achievement during the college years. Furthermore, male students on the eight HBCU campuses in Allen's study had higher educational and career aspirations, reported more favorable relationships with faculty, tended to be more involved in campus activities, and were noticeably more satisfied than African American women. Much like the female participants in previous studies (Fleming; Gurin \& Epps, 1975), the women in Allen's sample typically did not aspire to careers in fields traditionally occupied by men. These researchers suggested that social passivity and disengagement were obvious explanations for why exceptional academic achievement did not lead to high postgraduate educational and career aspirations among African American women at HBCUs.

Again, researchers have not thoroughly investigated gender differences in student engagement and satisfaction at HBCUs since the Fleming and Allen studies in the 1980s. Thus, the following questions remain unanswered: Do significant gender differences in engagement still exist among contemporary HBCU students? What areas of student engagement, if any, remain particularly low for African American women on historically Black campuses? Given the outcomes associated with high levels of engagement, are men still gaining more from their undergraduate experiences and reporting higher degrees of satisfaction than their female peers at HBCUs? These questions are explored in the current study.

\section{METHOD}

\section{Data Source}

Data were collected through the National Survey of Student Engagement (NSSE), a project that annually gathers information directly from undergraduate students and assesses the extent to which they are engaged in educational practices related to high levels of learning and development (Kuh, 2001). Institutional participation in NSSE is voluntary. More than 730 different postsecondary institutions and over 400,000 students took part in the project during the first 4 years of its administration. Once an institution agrees to participate, a random sample of first-year students and seniors are given the opportunity to complete the survey. The sample size at each institution is shaped by undergraduate enrollment and mode of administration. The average institutional response rate for NSSE 2000 and 2001 was approximately $42 \%$ (NSSE, 2000, 2001). Institutions participating in NSSE generally mirror the national profile with respect to institutional type (as defined by the 2000 Carnegie Classification), sector (public or private), region of the country, and degree of urbanization (NSSE, 2000, 2001).

\section{Sample}

To study possible gender differences in engagement, the responses of 1,167 African American undergraduates attending 12 HBCUs (9 public and 3 private) who completed the NSSE survey in 2000 or 2001 were analyzed. This group included 919 women and $248 \mathrm{men}$. Moreover, the sample included 547 first-year students and 620 seniors. The respondents represented a wide variety of academic majors (see Table 1). In general, the student and institutional profiles of the sample, although not fully representative of all HBCU institutional types, appear to mirror national profile trend data. The seeming overrepresentation of women in the sample is somewhat reflective of African American undergraduate enrollment trends across postsecondary institutions. For 
instance, women comprised nearly two thirds $(63 \%)$ of African American undergraduate enrollments in 2000, which was the highest proportion of female participation among all racial/ethnic groups in higher education (National Center for Education Statistics, 2003). According to Harvey (2001), African American female enrollments at HBCUs $(61.1 \%)$ are consistent with this national trend.

\section{Instrument}

The College Student Report is the NSSE survey instrument (Kuh, 2000), which taps into student experiences on several dimensions: (a) involvement in different types of in-class and out-of-class activities, (b) participating in educationally enriching programs such as study abroad, internships, and senior capstone courses, (c) perceptions of collegiate contributions to educational, personal, and social development, (d) perceptions of the campus environment, such as institutional emphases and quality of interactions, and (e) satisfaction with the overall college experience. In addition, students are asked to provide background information, such as their sex, race/ethnicity, enrollment status, living arrangements, and major field. Several administrations of the survey suggest that NSSE data have acceptable levels of reliability and validity. The NSSE National Report (2001) and Kuh et al. (2001) discussed the psychometric properties of The College Student Report in detail.

\section{Variable Specification}

We examined possible differences between the engagement levels of women and men on the following eight dimensions: (a) Academic Challenge, which measures the nature and amount of academic work performed; (b) Active and Collaborative Learning, which measures degrees of participation in the classroom and in out-of-class activities; (c) Student-Faculty Interaction on different levels; (d) Supportive Campus Environment, which measures the extent to which the campus climate fosters student development; (e) General Education Gains attributable to the institution in writing, speaking, and thinking critically; (f) Personal and Social Gains in the areas of personal and community-related issues; (g) Practical Competence Gains involving job-linked skills; and (h) Satisfaction with the institution. Table 2 shows descriptive statistics for measures of student engagement examined in this paper, including means for women and men sep-

TABLE 1.
Selected Academic Majors by Class and Sex

\begin{tabular}{|c|c|c|c|c|}
\hline \multirow[b]{2}{*}{ Major $^{\mathrm{a}}$} & \multicolumn{2}{|c|}{$\begin{array}{l}\text { First-Year } \\
\text { Students }\end{array}$} & \multicolumn{2}{|c|}{ Seniors } \\
\hline & $\begin{array}{c}\text { Women } \\
\%\end{array}$ & $\begin{array}{c}\text { Men } \\
\%\end{array}$ & $\begin{array}{c}\text { Women } \\
\%\end{array}$ & $\begin{array}{c}\text { Men } \\
\%\end{array}$ \\
\hline $\begin{array}{l}\text { Biological/ } \\
\text { Life Sciences }\end{array}$ & 12 & 5 & 10 & 11 \\
\hline Business & 13 & 15 & 10 & 23 \\
\hline $\begin{array}{l}\text { Computer/Infor- } \\
\text { mation Sciences }\end{array}$ & 5 & 6 & 5 & 9 \\
\hline Education & 10 & 6 & 15 & 7 \\
\hline Engineering & 2 & 10 & 2 & 8 \\
\hline $\begin{array}{l}\text { Health-Related } \\
\text { Fields }\end{array}$ & 8 & 5 & 8 & 3 \\
\hline Humanities & 1 & 3 & 4 & 2 \\
\hline Physical Sciences & 2 & 2 & 4 & 2 \\
\hline $\begin{array}{l}\text { Public } \\
\text { Administration }\end{array}$ & 3 & 5 & 1 & 2 \\
\hline Social Sciences & 16 & 8 & 19 & 11 \\
\hline Multiple Majors & 15 & 10 & 8 & 3 \\
\hline
\end{tabular}

a Declared or expected. 
TABLE 2.

Weighted Means, Standard Deviations, and Descriptions of Student Engagement Measures by Sex

\begin{tabular}{|c|c|c|c|c|c|c|c|c|}
\hline Measure & Description & Metric & $\begin{array}{c}\text { Women } \\
M\end{array}$ & $\begin{array}{c}\text { Men } \\
M\end{array}$ & $\begin{array}{l}\text { Women } \\
\text { SD }\end{array}$ & $\begin{array}{c}\text { Men } \\
S D\end{array}$ & $\begin{array}{l}\text { Women } \\
\quad N\end{array}$ & $\begin{array}{c}\text { Men } \\
N\end{array}$ \\
\hline $\begin{array}{l}\text { Academic } \\
\text { Challenge }\end{array}$ & $\begin{array}{l}\text { Nature and amount of } \\
\text { academic work performed }\end{array}$ & $\begin{array}{l}\text { Sum of } \\
10 \text { items }\end{array}$ & 17.43 & 16.62 & 4.54 & 3.91 & 874 & 230 \\
\hline $\begin{array}{l}\text { Active and } \\
\text { Collaborative } \\
\text { Learning }\end{array}$ & $\begin{array}{l}\text { Frequency of class } \\
\text { participation and } \\
\text { collaborative learning }\end{array}$ & $\begin{array}{l}\text { Sum of } \\
7 \text { items }\end{array}$ & 10.96 & 10.67 & 3.51 & 3.39 & 897 & 244 \\
\hline $\begin{array}{l}\text { Student-Faculty } \\
\text { Interaction }\end{array}$ & $\begin{array}{l}\text { Frequency of student } \\
\text { interactions with faculty }\end{array}$ & $\begin{array}{l}\text { Sum of } \\
6 \text { items }\end{array}$ & 7.98 & 8.49 & 3.78 & 3.72 & 890 & 240 \\
\hline $\begin{array}{l}\text { Supportive } \\
\text { Campus } \\
\text { Climate }\end{array}$ & $\begin{array}{l}\text { Degree to which the institution } \\
\text { is perceived to be supportive }\end{array}$ & $\begin{array}{l}\text { Sum of } \\
6 \text { items }\end{array}$ & 10.47 & 10.79 & 3.61 & 3.45 & 900 & 244 \\
\hline $\begin{array}{l}\text { Gains: General } \\
\text { Education }\end{array}$ & $\begin{array}{l}\text { Self-reported gains in writing, } \\
\text { speaking, and thinking critically }\end{array}$ & $\begin{array}{l}\text { Sum of } \\
4 \text { items }\end{array}$ & 12.73 & 12.68 & 2.58 & 2.42 & 904 & 242 \\
\hline $\begin{array}{l}\text { Gains: Personal } \\
\text { and Social }\end{array}$ & $\begin{array}{l}\text { Self-reported gains related to } \\
\text { personal and community issues }\end{array}$ & $\begin{array}{l}\text { Sum of } \\
7 \text { items }\end{array}$ & 20.61 & 20.20 & 4.87 & 4.73 & 894 & 241 \\
\hline $\begin{array}{l}\text { Gains: Practical } \\
\text { Competence }\end{array}$ & $\begin{array}{l}\text { Self-reported gains related to } \\
\text { job-related skills }\end{array}$ & $\begin{array}{l}\text { Sum of } \\
3 \text { items }\end{array}$ & 9.07 & 9.19 & 2.06 & 1.86 & 902 & 245 \\
\hline Satisfaction & Degree satisfied with institution & $\begin{array}{l}\text { Sum of } \\
2 \text { items }\end{array}$ & 6.02 & 5.98 & 2.06 & 1.86 & 911 & 245 \\
\hline
\end{tabular}

arately on each measure. We detailed each item contributing to the eight engagement measures in Appendix A. To minimize the possibility of a spurious relationship on engagement between the sexes, we controlled for several student factors that might confound sex differences (class, major field of study, enrollment status, and whether the student lived on campus).

\section{Statistical Model and Data Analysis}

Multivariate Ordinary Least Squares (OLS) regression was employed in our analyses on possible sex differences in engagement. Poststratification weights were applied to minimize nonresponse bias with respect to sex and enrollment status. Specifically, the overrepresentation of female respondents in the sample was adjusted by making the proportion of women and men for each school equal to the underlying proportions of female and male undergraduates on each campus (from IPEDS data). This minimizes the effects of having women respond more often to NSSE than men did. To ascertain if our findings had practical as well as statistical significance (Cohen, 1988), we report an effect size for each statistically significant difference found between women and men. Specifically, each unstandardized differential was divided between women and men by the pooled standard deviation for both sexes on the measure (i.e., a $y$-standardized coefficient) (Greenwald, Hedges, \& Laine 1996; Light \& Pillemer 1982; Pascarella, Flowers, \& Whitt, 2001). 


\section{RESULTS}

Table 3 shows OLS regression results comparing the engagement levels of women to men. All else being equal, significant differences between women and men were found on two measures: Academic Challenge and Student-Faculty Interaction (Column 2). Specifically, women reported more academic rigor than men did (.21 standard deviations more, Column 3), whereas men reported more contact with faculty than women did (.15 standard deviations more, Column 3). In contrast, significant gender differences did not exist for Active and Collaborative Learning, Supportive Campus Environment, Self-Reported Gains, or Satisfaction. The patterns in Table 3 appear robust; that is, they hold for both first-year students and seniors, still apply when we remove any one institution from the sample, and persist for both public and private institutions.

\section{DISCUSSION}

Three major studies of African American students during the 1970s and 1980s reported alarming findings about gender gaps on HBCU campuses (Allen, 1986; Fleming, 1984; Gurin \& Epps, 1975). Accordingly, African American women on these campuses were significantly less engaged than their same-race male peers. The results of the current study show that contemporary HBCU women no longer lag behind men in their academic and social engagement experiences. Overall, the engagement picture for women appears to be considerably less grim than in years past. Specifically, the results show no significant differences in the engagement levels of women and men on six of the eight measures examined in this study.

In addition to "catching up" with their male counterparts, women in the current study also scored significantly higher than men on the dimension of Academic Challenge, which is based on the amount of study time, reading, writing, and degree to which higher order thinking skills are required in courses, as opposed to student judgments about the difficulty of their coursework. Women in the sample spent more time preparing for class and worked harder than men to meet faculty expectations. The Academic Challenge results suggest a

TABLE 3.

OLS Multivariate Regressions of Engagement Measures on Sex and Selected Controls ${ }^{a}$

\begin{tabular}{lccc}
\hline & \multicolumn{3}{c}{ Women Versus Men } \\
\cline { 2 - 4 } Measure & $\begin{array}{c}\text { Unstnd } \\
\text { Coefficient }^{\text {b }}\end{array}$ & $\begin{array}{c}\text { Effect } \\
\text { Size }^{\mathbf{c}}\end{array}$ & $\begin{array}{c}\text { Adj } \\
\boldsymbol{R}^{\mathbf{2}} \text { d }\end{array}$ \\
\hline Academic Challenge & $.943^{* * *}$ & .21 & .029 \\
& $(.286)$ & & \\
Active and Collabor- & .272 & $\mathrm{NR}^{\mathrm{e}}$ & .092 \\
ative Learning & $(.213)$ & & \\
Student-Faculty & $-.584^{*}$ & -.15 & .089 \\
Interaction & $(.233)$ & & \\
Supportive Campus & -.261 & $\mathrm{NR}$ & .016 \\
Climate & $(.226)$ & & \\
Gains: General & .018 & $\mathrm{NR}$ & .023 \\
Education & $(.160)$ & & \\
Gains: Personal & .126 & $\mathrm{NR}$ & .034 \\
and Social & $(.306)$ & & \\
Gains: Practical & -.071 & $\mathrm{NR}$ & .055 \\
Competence & $(.124)$ & & \\
Satisfaction & .040 & $\mathrm{NR}$ & .020 \\
& $(.090)$ & & \\
\hline
\end{tabular}

$* p<.05 . \quad * * p<.01 . \quad * * * p<.001$ (two-tailed), standard errors in parentheses.

a Controls include class, enrollment status, major field, and whether living on campus.

b Unstandardized coefficient.

c $y$-standardized coefficient.

d Adjusted $R^{2}$.

e NR = Not Reported, coefficient not statistically significant. 
dramatic shift from previous findings where male dominance in the classroom generated passivity and unfavorable outcomes for female students at HBCUs. As African American women have enrolled in higher education institutions, including HBCUs, in greater numbers, they are clearly the classroom majority, which possibly contributes to their higher level of engagement on the Academic Challenge dimension.

Despite the overall engagement gains experienced by the women in this sample, men continue to interact more frequently with HBCU faculty than their female counterparts, as was the case in Fleming's (1984) study. Even though women put more effort into academic preparation and are as actively engaged in classroom and out-of-class activities, perhaps men interact more with faculty to compensate for their lower levels of course preparation. Men may dominate face time with faculty simply because they spend less time actually preparing for class and completing assignments, therefore requiring additional in-class and out-of-class attention. This is conjecture and additional research is needed to determine the causes for this tendency toward stronger studentfaculty interactions for African American males at HBCUs. This was the only dimension on which men scored significantly higher than women.

That significant differences between women and men on other dimensions of the survey were not found further illustrates the shift in student engagement by gender at HBCUs. Lack of statistically significant differences between female and male respondents on the dimension of Supportive Campus Environment contradicts previous research that reported evidence of women feeling less supported by their institutions than men did. Though they interacted less frequently with faculty, the female respondents perceived their campuses to be as supportive as the men in the sample did. The fact that the findings are steady from the first year to the senior year further indicates that women and men at HBCUs are being equally supported throughout their entire period of matriculation. The lack of significance on the Satisfaction dimension is also noteworthy, as previous generations of male students at HBCUs were far more satisfied with their experiences (Allen, 1986; Fleming, 1984).

Though not central to engagement, the majors reported by the seniors are also worth mentioning (see Table 1). There appears to be parity in the representation of women and men in the biological/life sciences, business, and physical sciences, majors traditionally chosen by male undergraduates (Lackland \& De Lisi, 2001). Women remain overrepresented in the health-related and education majors. Likewise, technical fields like engineering and computer/information sciences appear to attract more men than women. Women and men are equally represented in each of the other majors reported in Table 1-give or take some percentage points. Overall, the distribution of majors among female and male students illustrates that undergraduate women are at least selecting more majors outside of the traditional female sector of the job market, which shows great improvement since the 1970s and 1980s.

\section{IMPLICATIONS}

The findings of this study bode well for African American women and men alike and their engagement experiences on historically Black campuses. It is apparent that male students at HBCUs no longer, as Fleming (1984) put it, "gain the most" out of college. 
Instead, women and men are enjoying comparable gains, at least on the measures explored here. It therefore appears that women have overcome the engagement odds and social passivity of years past. Additional research is needed to determine the validity of this assumption. Female HBCU students, though reporting similar engagement patterns as men, may still cede to their male counterparts in class discussions, social settings, and student organizations.

The results regarding the Supportive Campus Environment and Satisfaction measures also merit additional exploration. If men are equally satisfied, perceive their campuses to be as supportive, and interact more with faculty than women do, why are their persistence rates so low? Mortenson (2001) found that more than 2 out of 3 African American undergraduate men discontinue their education prior to attaining baccalaureate degrees. Though it is often assumed that PWIs are largely responsible for the high attrition rates of African American students, recent data from the National Collegiate Athletic Association (NCAA) report that in 2003 only 10 HBCUs had African American student retention and graduation rates above $50 \%$ - based on sixyear graduation rates for all students, including nonathletes (NCAA, 2004). The rates for men were especially low, with only four HBCUs (including one men's college) graduating more than half of their African American male undergraduates.

The data reported in the current study suggest that the insufficient time and effort African American men devote to studying, reading, writing lengthy papers, preparing for class, and critically engaging assigned material may contribute (at least partially) to the retention dilemma on HBCU campuses. In their interactions with under- graduate men - which are reportedly more frequent than with female students - perhaps HBCU faculty could encourage African American males to engage more meaningfully in academic preparation and hold them more accountable inside the classroom for demonstrating the investment of their outof-class time to such activities. Again, research is needed to determine why actively engaged African Americans, particularly male students, are not persisting or graduating in larger numbers on Black college campuses.

Additionally, research comparing the engagement experiences of HBCU undergraduates to their African American counterparts at PWIs would also contribute to the higher education literature. Though numerous HBCU-PWI comparative studies already exist, additional inquiry providing an update on how contemporary African American students in the two institutional settings spend their time could yield interesting findings. This research might also uncover some compelling differences between women and men on those campuses, as Harper (2004) found that African American male participation in student organizations and campus activities is woefully low at many PWIs.

Finally, the relationship between engagement for African American women at HBCUs, academic major selection, and the development of career aspirations deserves empirical exploration. The results reported in this study show that female students are now selecting majors in which men were once almost exclusively represented. The implications of this are numerous. An increased representation of African American women in nontraditional fields could impact classroom environments at HBCUs and create a broader knowledge base and 
economic foundation within the African American community. Determining whether this shift in major selection is translating into career gains for African American women will require research on the postbaccalaureate career choices of HBCU alumnae. The instrument did not ask the respondents to report their career aspirations. Though highly unlikely, women may be choosing traditionally masculine majors in greater numbers, but still aspiring to lower-level careers within those fields.

\section{LIMITATIONS}

This study has some limitations. First, the standard NSSE research design targets only first-year students and seniors. Sophomores and juniors certainly make up a sizeable portion of undergraduate student enrollments on all four-year college and university campuses, including HBCUs. An additional limitation of this study involves the onedimensionality of the methodology. Perhaps a triangulation of methods may expose a different set of findings regarding gender differences on Black college campuses. For instance, a qualitative study of institutional culture may yield contradictory findings with regard to the general engagement parity that appears to have been reached among women and men at HBCUs.

We acknowledge the potential limitations of using self-reported gains in this study. For instance, Pascarella (2001) noted that gain scores may be related to students' precollege characteristics, which we were unable to control for in this study. Although findings related to self-reported gains should be interpreted with caution, our overall gender patterns persist even with dependent variables other than gains. Perhaps the most glaring limitation of this study is that the instrument measures degrees of engagement and satisfaction, not outcomes. It is assumed that active engagement in the seven dimensions explored in this study produces the same outcomes described in the existing involvement literature. The outcomes associated with engagement on these dimensions may be different for HBCU students.

\section{CONCLUSION}

This study, along with other demographic information illustrating the growing proportion of African American female students in higher education, paints the picture of an interesting and changing student engagement experience at HBCUs. Previous research on HBCU students consistently yielded troublesome findings regarding gender differences-men dominated the academic and social settings at HBCUs, which in turn led to greater outcomes and higher postbaccalaureate career ambitions. Although men still interact more frequently with faculty than their female classmates do, their overall dominance appears to have subsided considerably. Women have come to enjoy an equally engaging experience at HBCUs, while devoting significantly greater effort to their academic endeavors. This demonstrates that the African American student experience at HBCUs has evolved and ongoing data collection at these institutions is warranted to track and respond appropriately to gender gaps.

Correspondence concerning this article should be addressed to Shaun R. Harper, University of Southern California, Rossier School of Education, 3470 Trousdale Parkway, Suite 802, Los Angeles, CA 90089-4038; sharper@usc.edu 
APPENDIX A.

Survey Items Contributing to Student Engagement Measures

\section{Academic Challenge}

(Cronbach's alpha $=.73$ )

- Number of hours in a typical week preparing for class (studying, reading, writing, rehearsing, and other academic activities)

- Number of assigned textbooks, books, or book-length packs of course readings during the current school year

- Number of written papers or reports of 20 pages or more during the current school year

- Number of written papers of fewer than 20 pages during the current school year

- Extent to which coursework emphasized this school year: Analyzing the basic elements of an idea, experience or theory such as examining a particular case or situation in depth and considering its components

- Extent to which coursework emphasized this school year: Synthesizing and organizing ideas, information, or experiences into new, more complex interpretations and relationships

- Extent to which coursework emphasized this school year: Making judgments about the value of information, arguments, or methods such as examining how others have gathered and interpreted data and assessing the soundness of their conclusions

- Extent to which coursework emphasized this school year: Applying theories or concepts to practical problems or in new situations

- How often worked harder than you thought you could to meet an instructor's standards or expectations at your institution this school year?

- Extent to which your institution emphasizes: Spending significant amounts of time studying and on academic work

\section{Active and Collaborative Learning (Cronbach's alpha $=.67$ )}

- How often asked questions in class or contributed to class discussions at your institution during the current school year?

- How often made a class presentation at your institution during the current school year?

- How often worked with other students on projects during class at your institution during the current school year?

- How often worked with classmates outside of class to prepare class assignments at your institution during the current school year?

- How often tutored or taught other students at your institution during the current school year?

- How often participated in a communitybased project as part of a regular course at your institution during the current school year?

- How often discussed ideas from your reading or classes with others outside of class (students, family members, coworkers, etc.) at your institution during the currents school year?

\section{Student-Faculty Interaction (Cronbach's alpha $=.71)$}

- How often discussed grades or assignments with an instructor at your institution during the current school year?

- How often talked about career plans with a faculty member or advisor at your institution during the current school year?

- How often discussed ideas from your reading or classes with faculty members outside of class at your institution during the current school year?

- How often worked with faculty members on activities other than coursework at your

continues 
APPENDIX A. continued

institution during the current school year?

- How often received prompt feedback from faculty on your academic performance at your institution during the current school year?

- Done or plan to work with a faculty member on a research project

\section{Supportive Campus Environment (Cronbach's alpha $=.78$ )}

- Extent to which your college emphasized this school year: Providing the support you need to succeed academically

- Extent to which your college emphasized this school year: Helping you cope with your nonacademic responsibilities (family, work, etc.)

- Extent to which your college emphasized this school year: Providing the support you need to thrive socially

- Rate the quality of relationships with other students

- Rate the quality of relationships with faculty members

- Rate the quality of relationships with administrative personnel and offices

\section{General Education Gains (Cronbach's alpha $=.80)$}

\section{Extent to which your experience at this} institution contributed to your knowledge, skills, and personal development in:

- Acquiring a broad general education

- Writing clearly and effectively

- Speaking clearly and effectively

- Thinking critically and analytically

\section{Personal-Social Gains} (Cronbach's alpha $=.83$ )

Extent to which your experience at this institution contributed to your knowledge, skills, and personal development in:

- Working effectively with others

- Voting in elections

- Learning effectively on your own

- Understanding yourself

- Understanding people of other racial and ethnic backgrounds

- Being honest and truthful (2000) or Developing a personal code of values and ethics (2001)

- Contributing to the welfare of your community

\section{Practical Competence Social Gains (Cronbach's alpha $=.63$ )}

Extent to which your experience at this institution contributed to your knowledge, skills, and personal development in:

- Acquiring job- or work-related knowledge and skills

- Analyzing quantitative problems

- Using computing and information technology

\section{Satisfaction (Cronbach's alpha $=.73$ )}

- How would you evaluate your entire educational experience at this institution?

- If you could start over again, how likely are you to go the same institution you are now attending? 


\section{REFERENCES}

Allen, W. R. (1986). Gender and campus differences in Black student academic performance, racial attitudes, and college satisfaction. Atlanta, GA: Southern Education Foundation.

Anaya, G. (1996). College experiences and student learning: The influence of active learning, college environments, and cocurricular activities. Journal of College Student Development, 37, 611-622.

Bandura, A., Peluso, E. A., Ortman, N., \& Millard, M. (2000). Effects of peer education training on peer educators: Leadership, self-esteem, health knowledge, and health behaviors. Journal of College Student Development, 41, 471-478.

Baxter Magolda, M. B. (1992). Cocurricular influences on college students' intellectual development. Journal of College Student Development, 33, 203-213.

Berger, J. B., \& Milem, J. F. (1999). The role of student involvement and perceptions of integration in a causal model of student persistence. Research in Higher Education, 40(6), 641-664.

Berger, J. B., \& Milem, J. F. (2000). Exploring the impact of historically Black colleges in promoting the development of undergraduates' self-concept. Journal of College Student Development, 41, 381-394.

Bohr, L., Pascarella, E. T., Nora, A., \& Terenzini, P. T. (1995). Do Black students learn more at historically Black or predominantly White colleges. Journal of College Student Development, 36, 75-85.

Braxton, J. M., Hirschy, A. S., \& McClendon, S. A. (2004). Understanding and reducing college student departure. ASHE-ERIC Higher Education Report (Vol. 30, No. 3). San Francisco: Jossey-Bass.

Braxton, J. M., Milem, J. F., \& Sullivan, A. S. (2000). The influence of active learning on the college departure process: Toward a revision of Tinto's theory. The Journal of Higher Education, 71(5), 569-590.

Cabrera, A. F., Nora, A., Terenzini, P. T., Pascarella, E. T., \& Hagedorn, L. S. (1999) Campus racial climate and the adjustment of students to college: A comparison between White students and African American students. Journal of Higher Education, 70(2), 134-202.

Cheatham, H. E., Slaney, R. B., \& Coleman, N. C. (1990). Institutional effects on the psychosocial development of African-American college students. Journal of Counseling Psychology, 37, 453-458.

Chickering, A. W., \& Reisser, L. (1993). Education and identity (2nd ed.). San Francisco: Jossey-Bass.

Clarke, D., \& Tomlinson-Clarke, S. (1994). Predicting social adjustment and academic achievement for college women with and without precollege leadership. Journal of College Student Development, 35, 120-124.

Cohen, J. (1988). Statistical power analysis for the behavior sciences (2nd ed.). Hillsdale, NJ: Erlbaum.

Cokley, K. (1999). Reconceptualizing the impact of college racial composition on African American students' racial identity. Journal of College Student Development, 40 , 235-246
Delvin, A. S. (1996). Survival skills training during freshman orientation: Its role in college adjustment. Journal of College Student Development, 37, 324-334.

DeSousa, D. J., \& Kuh, G. D. (1996). Does institutional racial composition make a difference in what Black students gain from college? Journal of College Student Development, 37, 257-267

Evans, N. J. (1987). A framework for assisting student affairs staff in fostering moral development. Journal of Counseling and Development, 66, 191-193.

Fleming, J. (1984). Blacks in college: A comparative study of students' success in Black and in White institutions. San Francisco: Jossey-Bass.

Flowers, L., \& Pascarella, E. T. (1999). Does college racial composition influence the openness to diversity of African American students? Journal of College Student Development, 40, 377-389.

Gilligan, C. (1993). In a different voice: Psychological theory and women's development. Cambridge, MA: Harvard University Press.

Greenwald, R., Hedges, L. V., \& Laine, R. D. (1996). The effect of school resources on student achievement. Review of Educational Research, 66, 361-396.

Gurin, P., \& Epps, E. G. (1975). Black consciousness, identity and achievement: A study of students in historically Black colleges. New York: Wiley Press.

Harper, S.R. (2004). The measure of a man: Conceptualizations of masculinity among high-achieving African American male college students. Berkeley Journal of Sociology, 48(1), 89-107.

Harvey, W. B. (2001). Minorities in higher education, 2000 2001: Eighteenth annual status report. Washington, DC: American Council on Education.

Harvey, W. B., \& Williams, L. E. (1996). Historically Black colleges and universities: Models for increasing minority representation. In C. Turner, M. Garcia, A. Nora, \& L. I. Rendon (Eds.), Racial and ethnic diversity in higher education, ASHE Reader Series (pp. 233-240). Needham Heights, MA: Simon \& Schuster.

Jones, C. E., \& Watt, J. D. (1999). Psychosocial development and moral orientation among traditional-aged college students. Journal of College Student Development, 40, 125-132.

Kuh, G. D. (1995). The other curriculum: Out-of-class experiences associated with student learning and personal development. Journal of Higher Education, 66(2), 123-155.

Kuh, G. D. (2000). The college student report. Bloomington: National Survey of Student Engagement, Indiana University Center for Postsecondary Research.

Kuh, G. D. (2001). Assessing what really matters to student learning: Inside the National Survey of Student Engagement. Change, 33(3), 10-17, 66.

Kuh, G. D., Hayek, J. C., Carini, R. M., Ouimet, J. A., Gonyea, R. M., \& Kennedy, J. (2001). NSSE technical and norms report. Bloomington: National Survey of Student Engagement, Indiana University Center for Postsecondary Research. 
Kuh, G. D., Schuh, J. H., Whitt, E. J., Andreas, R. E., Lyons, J.W., Strange, C. C., Krehbiel, L. E., \& MacKay, K.A. (1991). Involving colleges: Successful approaches to fostering student learning and development outside the classroom. San Francisco: Jossey-Bass.

Lackland, A. C., \& De Lisi, R. (2001). Students' choices of college majors that are gender traditional and nontraditional. Journal of College Student Development, 42, 39-48.

Liddell, D. L., \& Davis, T. L. (1996). The measure of moral orientation: Reliability and validity evidence. Journal of College Student Development, 37, 485-493.

Light, R., \& Pillemer, D. (1982). Numbers and narrative: Combining their strengths in research reviews. Harvard Educational Review, 52, 1-26.

Milem, J. F., \& Berger, J. B. (1997). A modified model of college student persistence: Exploring the relationship between Astin's theory of involvement and Tinto's theory of student departure. Journal of College Student Development, 38, 387-400.

Mortenson Research Seminar on Public Policy Analysis of Opportunity for Postsecondary Education (2001, July). College participation by gender age 18 to 24,1967 to 2000. Postsecondary Education Opportunity, 109, pp. $1-16$.

National Center for Education Statistics. (2003). Status and trends in the education of Blacks. Washington, DC: U.S. Department of Education, Institute of Education Sciences, NCES.

National Collegiate Athletic Association. (2004). 2003 NCAA graduation rates report. Indianapolis, IN: Author.

National Survey of Student Engagement. (2000). NSSE 1999 overview. Bloomington: Indiana University Center for Postsecondary Research.

National Survey of Student Engagement. (2001). NSSE 2000 overview. Bloomington: Indiana University Center for Postsecondary Research.

NSSE 2001 National Report. (2001). Improving the college experience: National benchmarks of effective educational practice. Indiana University Center for Postsecondary Research. [On-line]. Available: www.indiana.edu/ $\% 7$ Ensse/html/toviewpoint2001.html.
Ory, J., \& Braskamp, L. (1988). Involvement and growth of students in three academic programs. Research in Higher Education, 28, 116-129.

Pascarella, E. T. (2001). Using student self-reported gains to estimate college impact: A cautionary tale. Journal of College Student Development, 42, 488-492.

Pascarella, E. T., Flowers, L., \& Whitt, E. J. (2001). Cognitive effects of Greek affiliation in college: Additional evidence. NASPA Journal 38(3), 280-301.

Pascarella, E. T., Smart, J., Ethington, C., \& Nettles, M. (1987). The influence of college on self-concept: A consideration of race and gender differences. American Educational Research Journal, 24, 49-77.

Paul, E. L., \& Kelleher, M. (1995). Precollege concerns about losing and making friends in college: Implications for friendship satisfaction and self-esteem during the college transition. Journal of College Student Development, 36, 513-521.

Peltier, G. L., Laden, R., \& Matranga, M. (1999). Student persistence in college: A review of research. Journal of College Student Retention, 1(4), 357-375.

Pike, G. R. (2000). The influence if fraternity or sorority membership on students' college experiences and cognitive development. Research in Higher Education, 41, 117-139.

Rest, J. R. (1993). Research on moral judgment in college students. In A. Garrod (Ed.), Approaches to moral development (pp. 201-213). New York: Teachers College Press.

Taylor, C. M., \& Howard-Hamilton, M. F. (1995). Student involvement and racial identity attitudes among African American males. Journal of College Student Development, 36, 330-336.

Tinto, V. (1993). Leaving college: Rethinking the causes and cures of student attrition (2nd ed.). Chicago: University of Chicago Press.

Watson, L. W., \& Kuh, G. D. (1996). The influence of dominant race environments on student involvement, perceptions, and educational gains: A look at historically Black and predominantly White liberal arts institutions. Journal of College Student Development, 37, 415-424. 